\title{
The Emphases and Strategies of University Student Management from the Perspective of People-Oriented
}

\author{
Zhengguang Xie \\ Southwest Petroleum University, Chengdu, China \\ Email: 546728036@qq.com
}

How to cite this paper: Xie, Z. G. (2021). The Emphases and Strategies of University Student Management from the Perspective of People-Oriented. Open Journal of Social Sciences, 9, 555-562.

https://doi.org/10.4236/jss.2021.99040

Received: August 27, 2021

Accepted: September 24, 2021

Published: September 27, 2021

Copyright $\odot 2021$ by author(s) and Scientific Research Publishing Inc. This work is licensed under the Creative Commons Attribution International License (CC BY 4.0).

http://creativecommons.org/licenses/by/4.0/

\begin{abstract}
From the perspective of innovative teaching, improving the effectiveness of the teaching of ideological and political subjects for college students is an important goal of talent cultivation in colleges and universities. There is no doubt that the cultivation of talents in colleges and universities must meet the talent needs of social development, and to promote the scientific, healthy and sustainable development of society, it is necessary to cultivate outstanding talents with scientific values, world outlook, and outlook on life. At present, the teaching philosophy of ideological and political subjects in China's colleges and universities is lagging, the teaching methods of ideological and political subjects are single, and the teaching content of ideological and political subjects is outdated. These are the three core problems in college students' ideological and political teaching from the perspective of innovative teaching. In view of this, this article believes that in order to improve the effectiveness of the teaching of ideological and political subjects in colleges and universities from the perspective of innovative teaching, it is necessary to accelerate the transformation of the teaching concept of ideological and political subjects in colleges, accelerate the reform of the teaching system of ideological and political subjects in colleges, and strengthen the faculty of ideological and political subjects in colleges and universities. Cultivation, the implementation of multiple measures together, form a joint force for the reform of ideological and political education, and ultimately can significantly improve the effectiveness of ideological and political education for college students.
\end{abstract}

\section{Keywords}

Innovative Teaching, College Students, Ideological and Political Teaching, Actual Effect, Teaching Mode Reform 


\section{Introduction}

As our country enters a new era of socialist construction, the development of our country's society, culture, economy, science and technology, and politics requires more high-quality talents. In modern society, high-quality talents must possess comprehensive qualities of diversification, broad vision, and multiple disciplines. In essence, outstanding talents have two abilities: On the one hand, outstanding talents must have strong professional knowledge and a certain academic level, have made great achievements in the professional field, and have certain research capabilities; On the other hand, excellent talents must have the correct outlook on life, world outlook, and values, be able to correctly handle the relationship between man and nature, and the relationship between man and society. Highquality talents must be able to view the world scientifically, rationally, dialectically and objectively, and view the objective world with a dialectical perspective. Only in this way can outstanding talents be able to exert their professional talents and make their due contributions to social development. At the same time, high-quality talents will also influence people around them in a subtle way, so as to provide a good working atmosphere for socialist modernization (Du \& Zuo, 2019).

In this situation, in the process of cultivating college students, colleges and universities must also pay great attention to the importance of college students' ideological and political teaching, and truly fundamentally improve the effectiveness of college students' ideological and political teaching. In the teaching of ideological and political subjects, teachers must aim to improve the effectiveness of teaching, continuously innovate and reform teaching methods, methods, and models, and continue to improve the teaching efficiency and effectiveness of ideological and political subjects. In view of this, this article is based on the research perspective of innovative teaching, and explores the problems existing in the ideological and political teaching of college students from the perspective of innovative teaching. Contribute to the sustainable development of education (Liu Bowen, 2015).

This article first analyzes the key points of college student management, establishes a human-oriented educational philosophy, combines the difficulties and trends of college student management, and proposes specific measures to optimize college student management, which has certain theoretical value and practical significance.

\section{Analysis of the Problems Existing in the Ideological and Political Teaching of College Students from the Perspective of Innovative Teaching}

In order to conduct a more comprehensive, scientific and reasonable research on the countermeasures to improve the effectiveness of the teaching of ideological and political subjects in colleges and universities, this article first analyzes the problems existing in the ideological and political teaching of college students 
from the perspective of innovative teaching, and concludes that: at present, the thinking of colleges and universities in our country The lagging teaching concept of the political discipline, the single teaching method of the ideological and political discipline, and the outdated teaching content of the ideological and political discipline are the three core problems in the ideological and political teaching of college students from the perspective of innovative teaching. The specific analysis is as follows.

\subsection{The Teaching Concept of Ideological and Political Subjects Is Lagging behind}

The teaching concept of ideological and political subjects is lagging behind, which is the primary problem in the teaching of ideological and political subjects for college students from the perspective of innovative teaching (Qi Yuexiang, 2020).

First, many college teachers of ideological and political subjects believe that the focus of ideological and political education and teaching is subject research, so their teaching focuses mainly on the field of scientific research, ignoring the importance of ideological and political education in students' daily life and learning Guiding value and meaning. Therefore, many colleges and universities have relaxed their requirements on the teaching of ideological and political subjects for college students.

Second, the teaching of ideological and political subjects in colleges and universities still has the misunderstanding of "book-based" and "dogmatic", lacks a dialectical understanding of ideological and political subjects, and it is difficult to truly apply the content of ideological and political subjects and cannot keep up with the times. Progressively adjust and optimize the teaching, key points and teaching objectives of the ideological and political subjects, which makes it difficult for the teaching of the ideological and political subjects to keep up with the needs of the times. (Tang \& Zhang, 2018)

Third, at present, the teaching philosophy of ideological and political subjects in colleges and universities is limited to classroom teaching, ignoring the value guidance and ideological enlightenment of college students in daily life, which severely restricts the improvement of the timeliness of college students' ideological and political subjects teaching, and it is also difficult Arouse the enthusiasm of college students.

\subsection{The Teaching Method of Ideological and Political Subjects Is Single}

The single teaching method of ideological and political subjects is the core problem of ideological and political teaching of college students under the perspective of innovative teaching. (Wang Huanhuan, 2017)

First of all, teachers of ideological and political subjects in universities and colleges often pay too much attention to classroom theory teaching and the scores of college students' ideological and political subjects. This will make the teaching 
of ideological and political subjects very monotonous and boring, which makes it difficult to attract college students' interest in ideological and political subjects. This will cause college students to reject the study of ideological and political subjects, and will not help colleges and universities to guide college students to form a correct outlook on life, world outlook and values. Therefore, colleges and universities must pay attention to practical teaching, "really work hard", and comprehensively improve the effectiveness of the teaching of ideological and political subjects.

Secondly, due to the lack of professional abilities of teachers of ideological and political subjects, their teaching methods are relatively rigid, they are not good at using diversified teaching tools and methods, and cannot make full use of scientific and technological means to enhance the interest and timeliness of classroom teaching of ideological and political subjects, which Affected the improvement of the effectiveness of college students' ideological and political teaching. (Wang Shuai, 2017)

Furthermore, as mentioned above, due to the widespread passive status quo that emphasizes theory and neglects practice in the teaching of ideological and political subjects, it is difficult for students to feel the importance and necessity of ideological and political education in daily life, and it is extremely easy to form in colleges and universities. An environment in which the teaching of ideological and political subjects is not important makes ideological and political education a form without actual teaching content. This is also not conducive to the improvement of the effectiveness of college students' ideological and political education. (Wang Wei, 2018)

\subsection{The Teaching Content of Ideological and Political Subjects Is Outdated}

The teaching content of ideological and political subjects is outdated, which is one of the main problems existing in the ideological and political teaching of college students from the perspective of innovative teaching.

First, with the rapid development of my country's economy, my country's society, economy, culture, politics, and technology have undergone earth-shaking changes, and people's living standards have continued to improve. The teaching content of traditional ideological and political subjects has been difficult to fully satisfy our society. The objective needs of the modernization of socialism. Therefore, colleges and university teachers must continuously optimize and update the teaching content of ideological and political subjects. However, the current content update in this field of colleges and universities is relatively lagging, which will reduce the interest of the teaching of ideological and political subjects in colleges and universities, and it is difficult to keep up with the times. Enter (Wang Xiao, 2020).

Secondly, when Jin's world is facing "great changes unseen in a century", the domestic and international environments have undergone earth-shaking changes. Ideological and political disciplines are important disciplines and effective ways 
to guide college students' values, outlook on life, and world outlook. It is necessary to attach great importance to changes in the domestic and international situation, to implant the elements of the times into the teaching of ideological and political subjects, and to enhance the effectiveness and timeliness of ideological and political education.

Third, colleges and universities should enhance the vitality of ideological and political teaching, not only for the subject education of ideological and political subjects in colleges and universities, but also integrate the content of ideological and political education into other subjects, so as to give play to the "classroom ideological and political" (in other subject classrooms).

\section{Specific Strategies to Improve the Effectiveness of Ideological and Political Teaching for College Students from the Perspective of Innovative Teaching}

Based on the previous theoretical analysis, combined with the objective status quo of low effectiveness of ideological and political education for college students in China, and the basic requirements of innovative teaching, this article believes that in the perspective of innovative teaching, improving the timeliness of college students' ideological and political education mainly includes three The specific aspects are as follows: from the perspective of innovative teaching, in order to improve the effectiveness of the teaching of ideological and political subjects for college students, it is necessary to accelerate the transformation of the teaching concept of ideological and political subjects in colleges and universities, accelerate the reform of the teaching system of ideological and political subjects in colleges, and strengthen the teachers of ideological and political subjects in colleges and universities. The cultivation of the team and the implementation of various measures together form a joint force for the reform of ideological and political education, which can ultimately significantly improve the effectiveness of ideological and political education for college students (Wang Roujian, 2020).

\subsection{Accelerate the Transformation of Teaching Concepts of Ideological and Political Subjects in Colleges and Universities}

Speeding up the transformation of the teaching concepts of ideological and political subjects in colleges and universities is a basic strategy to improve the effectiveness of ideological and political teaching of college students from the perspective of innovative teaching.

First, it is necessary to clarify the core objectives of the teaching of ideological and political subjects in colleges and universities. The core goal of ideological and political teaching in colleges and universities is to guide students to form a correct outlook on life, world outlook, and values, and guide students to look at problems and the world in a dialectical, scientific, and objective ideological, so as to make students have good basic qualities. (Wei Jie, 2019)

Second, colleges and universities should change their traditional cognition of 
ideological and political subjects. On this basis, colleges and universities should change the passive status quo of emphasizing theory and neglecting practice, and ignoring humanities education. Colleges and universities should focus on the teaching of ideological and political subjects. Implanted into the teaching of various disciplines, truly explore the continuous expansion of the scope of application of "classroom ideological and political" content, and improve the effectiveness of ideological and political teaching.

\subsection{Accelerate the Reform of the Teaching System of Ideological and Political Subjects in Colleges and Universities}

Accelerating the reform of the teaching system of ideological and political subjects in colleges and universities is a key strategy to improve the effectiveness of ideological and political teaching for college students from the perspective of innovative teaching.

First, colleges and universities must continuously improve the teaching environment of ideological and political subjects. They must not only update the software and hardware equipment for teaching ideological and political subjects, but also pay attention to the optimization of teaching content (Wu \& Li, 2020).

Second, colleges and universities should analyze and reconstruct the teaching mode of ideological and political subjects, inherit and carry forward the advantages in the teaching of ideological and political subjects, and resolutely abandon the deficiencies in the teaching of ideological and political subjects. In the classroom, colleges and universities' teachers should clarify the leading position of students in the teaching of ideological and political subjects, actively stimulate students' self-thinking and independent thinking, and truly enhance students' sense of participation and gain.

Third, colleges and universities should optimize the assessment and evaluation of the teaching of ideological and political subjects. They should not only pay attention to the incentive and restraint of professional subject teachers under the ideological and political subject teaching system, but also pay attention to the assessment of administrative assistants in the field of ideological and political education of college students. It is necessary to actively guide teaching assistants to participate in the ideological and political education of college students, especially to enhance the value and role of college counselors.

\subsection{Strengthen the Cultivation of the Faculty of Ideological and Political Subjects in Colleges and Universities}

Strengthening the cultivation of the faculty of ideological and political subjects in colleges and universities is an important supplementary strategy for improving the effectiveness of ideological and political teaching of college students from the perspective of innovative teaching. (Yang \& She, 2020)

On the one hand, colleges and universities should cultivate existing teachers of ideological and political subjects, and continuously improve the professional qualities of teachers of ideological and political subjects by adopting various methods 
such as lectures, exchanges, competitions, and further studies. At the same time, colleges and universities should create conditions for teachers to continuously guide teachers to use new technologies and new tools to carry out ideological and political teaching, and improve the effectiveness of teaching, so that college ideological and political teachers can adapt to the teaching mode and content in the new era environment.

On the other hand, colleges and universities must actively introduce high-quality talents with rich teaching experience, and provide them with sufficient development space and platforms to truly promote the reform and innovation of ideological and political teaching in colleges and universities, and continuously improve the effectiveness of ideological and political teaching in colleges and universities (Zhao Cheng, 2020).

\section{Research Conclusion}

All in all, in the new era of socialism, improving the effectiveness of college students' ideological and political teaching is an educational issue that colleges and universities must attach great importance to, which determines the quality and level of my country's future economic, social, cultural, technological, and development. In the new era, colleges and universities must innovate educational methods, innovate educational concepts, and improve teaching methods. The threepronged approach and multiple measures must be taken to continuously improve the sense of acquisition, existence, and happiness of college students' ideological and political teaching, and truly enhance college students' ideological and political education. Based on a human-oriented research idea, this article analyzes in detail the problems and predicaments of college student management, and then analyzes the key points of college student management, and based on the key content of college student management, this article combines the actual situation of university education management and proposes feasible and scientific optimal countermeasures that have greater theoretical value and strong practical significance.

\section{Conflicts of Interest}

The author declares no conflicts of interest regarding the publication of this paper.

\section{References}

Du, J., \& Zuo, D. X. (2019). Research on the Effectiveness of Ideological and Political Teaching Based on Students' Sense of Acquisition. Journal of Suzhou Education College, 22, 78-80.

Liu, B. W. (2015). How to Strengthen the Effectiveness of Ideological and Political Education in Colleges and Universities. Asia Pacific Education, No. 28, 192.

Qi, Y. X. (2020). Research on the Dynamic Adjustment Mechanism of Ideological and Political Teaching under the Background of Mobile Internet. Reform and Opening, No. 16, 89-93. 
Tang, X. F., \& Zhang, H. T. (2018). Reinterpretation and Optimization of the Evaluation of Ideological and Political Teaching in Colleges and Universities from the Perspective of Educational Ecology. Heilongjiang Higher Education Research, No. 8, 128-131.

Wang, H. H. (2017). A Preliminary Study on the Effective Countermeasures to Promote the Ideological and Political Teaching in Tibetan Colleges and Universities in the New Era. Shanxi Agricultural Economics, No. 16, 146.

Wang, S. (2017). Study on the Improvement Path of Ideological and Political Education in Colleges and Universities from the Perspective of the Internet. Journal of Sichuan Cadre Correspondence College, No. 3, 52-54.

Wang, W. (2018). Cultivate the Core Values of College Students and Inject the Soul into Ideological and Political Teaching in Colleges and Universities. Think Tank Times, No. 33, $275+277$.

Wang, R. J. (2020). Study on the Supply Side of Classroom Teaching of Ideological and Political Courses in the New Era. Study, No. 24, 53-54.

Wang, X. (2020). Research on Improving the Effectiveness of Ideological and Political Course Teaching in Higher Vocational Colleges. Yangtze River Series, No. 28, 189-190.

Wei, J. (2019). Study on the Path to Improve the Effectiveness of Ideological and Political Education in Colleges and Universities under the New Media Environment. Media Forum, 2, 96+98.

Wu, J, \& Li, Q. X. (2020). The Sense of Acquisition of College Students' Ideological and Political Courses: Current Situation Analysis and Improvement Path. Journal of Luoyang Normal University, 39, 5-10.

Yang, S. P., \& She, Y. N. (2020). The Second Classroom Practice of Ideological and Political Teaching in Colleges and Universities from the Perspective of Marxist Practice View. Journal of Qiqihar University (Philosophy and Social Science Edition), No. 7, 186-188.

Zhao, C. (2020). On the Effectiveness of Information Technology and Ideological and Political Teaching. Southern Agricultural Machinery, 51, 120. 